\title{
ANALYSIS OF THE EU'S CENTRAL ASIA POLICY: FROM A PROJECT-ORIENTED APPROACH TO A NEW STRATEGIC PARTNERSHIP*
}

\author{
ERTAN EFEGIL
}

\begin{abstract}
The European Union provided technical assistance primarily to economic and commercial reforms, state-building processes, and encouragement of foreign investments in the period between 1996 and 2001 although it expressed that democratization and liberal market economy were integral parts of its mutual relations. However, the EU radically changed its Central Asia strategy after September 11, 2001 attacks. In its new Central Asia Strategy adopted in 2006 and in its relations, the Union has given priority to the political issues and expressed that human rights, democratization, good governance, eradication of poverty and others are now located at the center of the mutual relations. Yet, there are some serious handicaps, such as authoritarian mentality of the Central Asian states.
\end{abstract}

\section{KEYWORDS}

TACIS, PCA, European Union, Central Asia, European Security Strategy

${ }^{*}$ The paper has been presented at the conference organized by INST: Research Institute for Regional and Transnational Cultural Sciences, named as Knowledge, Creativity and Transformations of Societies, on 6 - 9 December 2007, in Vienna, Austria. 


\section{Introduction}

Following the collapse of former Soviet Union in 1991, the European Union immediately established bilateral and multilateral relations with the Central Asian states, especially within the framework of TACIS (Technical Assistance to the Commonwealth of Independent States) program ${ }^{1}$ and it signed Partnership and Cooperation Agreements (PCA) ${ }^{2}$ with each regional state.

In the period between 1996 and 2001, the European Union provided technical assistance primarily to economic and commercial reforms, state-building processes, and encouragement of foreign investments, although the Union expressed that democratization and liberal market economy were integral part of its mutual relations. Thus, these agreements were oriented towards concrete areas rather than political matters.

However, the Union radically changed its Central Asia strategy after the September 11, 2001 attacks. In its new regional strategy adopted in 2006, the Union, by giving priority to the political issues has stated that human rights, democratization, good governance and eradication of poverty are the central concepts in its new approach. Since then, the regional countries are entitled to receive assistance from the EU according to their performance in the field of political and economic reforms, regardless of their size in population and geography. Thus, the Union's policy has evolved from a projectbased one to a new strategic partnership approach based on the contemporary democratic values. But existing regional conditions, such as the authoritarian culture of the Central Asian countries, may prevent the EU's success in the region.

${ }^{1}$ For further information about the EU's Central Asia policy, see: Annan Matveeva, "EU Stakes in Central Asia", Chaillot Papers, No 91, Institute for Security Studies, July 2006.

${ }^{2}$ These agreements have created a suitable ground for the political, commercial, economic, social, financial, scientific and cultural cooperation between the Central Asian states and the European Union. They have also encouraged the regional leaders on the matters of democratization and free market economy. 
Hence, this study focuses on the change in the EU's Central Asia policy, examines the EU's new partnership strategy, and lastly makes some suggestions about the implementation of the new strategy.

\section{Priorities and Objectives of TACIS Programs: 1996 - 2000}

Since 1991, the Partnership and Cooperation Agreements (PCS) have been the legal basis of bilateral relations between the European Union and the Central Asian states. On the other hand, the TACIS program has formed an administrative framework for the technical assistance of the Union to the Central Asian states, including other former Soviet republics. The basic objectives of the TACIS program in the 1996 - 2000 period were a) to provide transition of the regional countries to free market economy, and b) to develop their democratic institutions. In this context, the Union concerned that the development of local economies and the better implementation of democratic institutions were more appropriate and rational ways to promote the political and economic stability in the region.

Until 2001, the TACIS program focused on mainly five sectors: 1) training 2) energy 3) transportation 4) industrial and commercial enterprises, and 5) food production. ${ }^{3}$ Thus, TACIS program was directed to concrete and lasting projects rather than political matters, such as democratization. The Union distributed the financial funds and technical assistances under TACIS to the following areas: improvement of small and medium-sized companies, banking training, reorganization of private companies, new legal regulations, agriculture, environment, transportation, energy, and telecommunication. ${ }^{4}$

\footnotetext{
${ }^{3}$ International Crisis Group, "Central Asia: What Role for the European Union”, Asia Report, No 113, 10 April 2006, p. 19.

${ }^{4}$ For further information about the PCA, see:

http://ec.europa.eu/external_relations/ceeca/pca/index.htm.
} 
Technical Assistances Provided to the Central Asian States (1996 - 1999)

\begin{tabular}{|c|c|}
\hline Country & Areas \\
\hline Kazakhstan & $\begin{array}{l}\text { Macroeconomic and sectoral policies, the development of } \\
\text { production, sustainable middle-term development, protection } \\
\text { of social groups, the reorganization of banking system, } \\
\text { customs management, environmental issues, reform in the } \\
\text { higher education, the reorganization of national oil company, } \\
\text { and membership to the World Trade Organization. }\end{array}$ \\
\hline Tacikistan & Humanitarian assistance and rehabilitation projects. \\
\hline Turkmenistan & $\begin{array}{l}\text { Improvement of the conditions of peasants, tax reform, } \\
\text { reform in higher education, privatization, the reorganization } \\
\text { of banking system, the development of oil and natural gas } \\
\text { sectors, the improvement of small and medium sized } \\
\text { companies, the development of cotton sector, the customs } \\
\text { management and the agriculture. }\end{array}$ \\
\hline Kyrgyzstan & $\begin{array}{l}\text { The development of private sector, the strengthening of the } \\
\text { transportation and infrastructure, postal services, the } \\
\text { development of national airline company and agricultural } \\
\text { industry, and reform in the higher education. }\end{array}$ \\
\hline Uzbekistan & $\begin{array}{l}\text { To restructure the Ministry of Education, regional projects } \\
\text { (TRACECA, INOGATE), to make the state institutions more } \\
\text { efficient, health reform and membership to the World Trade } \\
\text { Organization. }\end{array}$ \\
\hline
\end{tabular}

Source: http://ec.europa.eu/external_relations/ceeca/pca/index.htm. (20 November 2007).

On the other hand, the Central Asian states preferred to get the assistance for the purposes of strengthening administrative institutions, the encouragement of foreign investments, the improvement of education systems, the development of agricultural sectors, and making progress in the legal regulations rather than in democratization, respect for human rights and other political issues. 


\section{New Central Asia Strategy after 2001}

Since 2001, the European Union changed its regional strategy in a radical way due to its need for new external energy resources ${ }^{5}$, the emergence of regional issues that threaten both the security of the region as well as global security, and its enlargement process, thus the Central Asian and Caucasian states become its neighbours. Now, the Union gives priority to political issues, economic interests and security concerns. Such issues, especially development of democratic institutions, respect for human rights, good governance, and eradication of poverty have become more privileged. The EU would also engage in with both regional governmental institutions and local civil society organizations in the coming future.

Before defining its new regional strategy, the Union firstly adopted its new Security Strategy ${ }^{6}$ in 2003, in which it announced following issues, such as terrorism, distribution of weapons of mass destruction, regional conflicts, failed states, bad governance, corruption, abuse of power, existence of weak state institutions, and organized crimes as new threats of the post-Cold War era. On the other hand, the Union included the subjects of violation of human rights, the existence of authoritarian regimes, and other democracy related issues, as well as social, economic and environmental factors within the scope of the Security Strategy. So, the Union intends to find solutions to its security concerns within the framework of its Good Neighbourhood Policy?

${ }^{5}$ For further information about the EU's energy policies, see: Svein $\mathrm{S}$. Andersen, "EU Energy Policy: Interest Interaction and Supranational Authority", ARENA Working Papers, WP 00/5, http://www.arena.uio.no/publications/working-

papers2000/papers/wp00_5.htm. (1 June 2007); EU Commission, "Green Paper: A European Strategy for Sustainable, Competitive and Secure Energy", COM(2006) 105 Final, March 8, 2006; International Crisis Group, "Central Asia'a Energy Risks", No 133, 24 May 2007.

${ }^{6}$ For further information see: "European Parliament resolution on the European Security Strategy (2004/2167 (INI)", P6_TA (2005) 0133, Official Journal of the European Union, C33E/580, 9 February 2006.

${ }^{7}$ The European Neighbourhood and Partnership Instrument aims to strengthen the coopeation with neighbouring countries and to promote the contemporary values, such as democracy and human rights. According to 
Thus, the EU expects other countries to respect democracy and human rights, especially countries that are considered within the framework of the Good Neighbourhood Policy due to the fact that the Union has indeed viewed these concepts as a basis of having friendly relations among the states.

In line with new Security Strategy, the Union wants to enhance its relations with the Central Asian states in the fields expressed in the Strategy, such as terrorism, organized crime, regional issues, drug trafficking, and others. The Union officials have also concerned that stability, security and good governance in Central Asia is indispensable part of maintaining the security of the EU. For that reason, the EU urges former socialist countries to have democratic and pluralist regimes because promotion of good governance, fighting against corruption and abuse of power, the advancement of the rule of law, and respect for human rights have been considered as the integral parts of the Security Strategy.

Secondly, the Union has initiated an energy program, the Baku Initiative, for its security in energy supply in $2004 .^{8}$ Thus, the Union gives priority to the regional cooperation in order to reach regional energy resources, to encourage the discovery of new energy resources and to help repair existing energy infrastructure, and it tries to materialize the Central Asia - Black Sea - the European Union Energy Transportation Corridor. With the assistance of the Baku Initiative, the Union plans the creation of a Central Asian energy market.

Thirdly, the Union adopted its Instrument for Development Cooperation in 2005. With the Instrument, the Union plans to force

the Instrument, the countries have to respect to democracy, human rights, rule of law, good governance and other values in their domestic affairs and foreign relations. For further information about the Instrument, see: "Regulation (EC) No 1638/2006 of the European Parliament and of the Council of 24 October 2006 laying down general provisions establishing a European Neighbourhood and Partnership Instrument", Official Journal of the European Union, L310/1, 9 November 2006.

${ }^{8}$ For further information about the Baku Initiative, see: http://ec.europa.eu/external_relations/energy/baku_iniative/index.htm. 
the countries, which have relations with it, to act in conformity with the UN Millennium Development Goals ${ }^{9}$ and the European Consensus. ${ }^{10}$ Thus, they will spend their energies to eradicate poverty, to develop universal fundamental education, gender equality, to secure women's rights, to improve health services and so on. In the meantime, they will help developing countries to integrate into the world economy.

Within the framework of new developments in world politics, especially after the September 11, 2001, and in favor of the European Security Strategy, the Baku Initiative, and the European Consensus, the European Union adopted its new Central Asia Strategy in 2006. ${ }^{11}$ Although the Strategy does not encourage the Union to become a party in the New Great Game, by mentioning strategic importance of the Central Asia region, the Union points out that the regional states should become more democratic, peaceful and economically developed countries.

\footnotetext{
${ }^{9}$ Some goals of the UN Millennium are to eradicate poverty and starvation, to improve universal basic education, to provide equality between man and woman, to secure the women's rights, to decrease death of children, to struggle with AIDS/HIV/Malaria, and to guarantee enviromental sustainability and global struggle for development. For further information, see: http://www.un.org/milleniumgoals/goals.html (16 September 16, 2007).

${ }^{10}$ Some aims of the Union's Development Instrument are eradication of poverty, and strengthening good governance and respect for human rights. For further information about the Instrument, see: "Joint Statement by the Council and the representatives of the governments of the member states meeting within the Council, the European Parliament and the Commission on European Union Development Policy: "The European Consensus"', 14820/05, DEVGEN 229, RELEX 678, ACP 155, 22 November 2005; "Regulation (EC) No 1905/2006 of the European Parliament and the Council of 18 December 2006 establishing a financing instrument for development cooperation", Official Journal of the European Union, L378/41, 27 December 2006.

${ }^{11}$ For further information, see: "The EU and Central Asia: Strategy for New Partnership", EU2007.de, EU-Central Asia-Strategy.pdf. (1 June 2007).
} 
In favor of new mentality, the Union will attempt to have regular political dialogue, ${ }^{12}$ to start the European Education and the European Rule of Law Initiatives, and to organize the Human Rights and the Energy Dialogues with the regional states. In this manner, the Union will take the following steps: to continue supporting human rights issues, to help the establishment and development of independent courts, to promote the legal reforms, to continue cooperating in the education field, and to support membership to the WTO, INOGATE ${ }^{13}$, TRACECA ${ }^{14}$ and other regional projects.

\section{The EU's Regional Strategies} strategies.

The European Union has prepared three different regional

\footnotetext{
${ }^{12}$ In 2004, the European Union established a regular regional political dialogue mechanism with the Central Asian states. Objectives of the Regional Dialogue are a) to assist the regional countries to negotiate their regional common issues, b) to give positive answer to the Central Asian states' demands of having close relations with the Union, and c) to support the EU Commission's Central Asia regional strategy. During the unofficial negotiations, the parties discussed the following issues; such as drug trafficking, use of water and energy resources, and fighting against the terrorism. In 2007, in Kazakhstan they came together and discussed economic and commercial issues, security, education, democracy, rule of law, human rights, energy, environmental and regional matters. In the period between $2007-2011$, they accepted to take concrete steps in order to eradicate poverty, to strengthen good governance, to reorganize state institutions and to create suitable conditions for foreign investment. For further information, see: "Ferrero - Waldner to attend EU - Central Asia Ministerial Troika 27/28 March", IP/07/420, 27 Mart 2007; International Crisis Group, Central Asia: What role, p. 19.

${ }^{13}$ INOGATE (The Interstate Oil and Gas Transport to Europe) is a regional project that the European Union initiated in order to provide its energy security.

${ }^{14}$ TRACECA (The Transport Corridor Europe - Caucasus - Asia) is a regional project, accepted by the Union during the Brussels Conference of 1993. It will connect the European Union with the Central Asian and Caucasian states via the Black Sea and the Caspian Sea.
} 
The first strategy, "Central Asia Regional Strategy Paper 2002 - 2006", was adopted in 1999 that covered the period between 2002 and $2006 .{ }^{15}$ Its basic objectives were to make contributions to the stabilities and securities of the regional states as well as making efforts to eliminate poverty and to contribute their sustainable economies. In this context, the European Union proposed to take concrete steps in the fields of security and conflict management, political and social difficulties, and lastly commerce and investments. Meanwhile, the EU Council expressed that it gave priority to the development of political dialogue, the eradication of poverty, social and economic development, good governance, fighting against the drugs, and border management.

However, the regional states again preferred to receive assistance in economic and administrative fields despite the EU's insistence that the assistance should go to political reforms.

Assistances to the Central Asian States between 2002 and 2006

\begin{tabular}{|c|l|}
\hline Country & \multicolumn{1}{|c|}{ Areas } \\
\hline Kazakhstan & $\begin{array}{l}\text { Supporting private sector, the management of natural } \\
\text { resources, education, the development of small- and } \\
\text { medium-sized companies. }\end{array}$ \\
\hline Uzbekistan & $\begin{array}{l}\text { Financial reform, membership to the World Trade } \\
\text { Organization, the reorganization of commercial } \\
\text { companies, the development of human resources, energy, } \\
\text { transportation, telecommunication, agriculture and } \\
\text { education. }\end{array}$ \\
\hline Kyrgyzstan & $\begin{array}{l}\text { Food security, agriculture and reform in the social sector, } \\
\text { and education. }\end{array}$ \\
\hline
\end{tabular}

Source: http://ec.europa.eu/external_relations/ceeca/c_asia/2002.htm.

${ }^{15}$ The European Union, "Strategy Paper 2002 - 2006 \& Indicative Programme 2002 - 2004 For Central Asia”, Council Regulation No 99/2000, 29 December 1999; the EU Commission, "TACIS Regional Cooperation: Strategy Paper and Indicative Programme 2004 - 2006”, 11 April 2003, http://ec.europa.eu/external_relations/ceeca/c_asia/2002.htm. 
The second strategy, "ENPI Eastern Regional Indicative Programme 2007 - 201016", gives priority to three fields: 1) the development of regional cooperation and Good Neighbourly relations in the Central Asia; 2) the eradication of poverty and the improvement of the living standards, and 3) good governance and economic reforms. So, the Program plans to provide assistance to the following subjects: education, energy, transportation, environment, border security, the development of civil society, social dialogue, democratic reforms, and legal reforms. ${ }^{17}$

The third one, "ENPI Eastern Regional Programme Strategy Paper 2007 - 2013 18", has repeated the basic principles of the previous strategies. The Program aims at supporting the political and economic transition of the region, strengthening the rule of law, democracy, good governance, and reinforcing the respect for human rights. It has indicated the following objectives:

1. to assure the stability and security of the Central Asia region,

2. to eradicate the poverty and to raise the living conditions,

3. to develop the regional cooperation on the subjects of energy, transportation, high education and environmental issues.

${ }^{16}$ The European Union, "Central Asia Indicative Programme (2007 - 2010)", Regulation (EC) No: 1905/2006, http://ec.europa.eu/external_relations/ceeca/c_asia/nip_07_10_en.pdf.

${ }^{17}$ Under the title of the Democratic Development and Good Governance, the Union plans to attempt 1) to develop respect for human rights and fundamental freedoms, 2) to establish national human rights institutions, 3) to provide participation of the public into the decision making processes, 4) to promote cooperation between governmental and non - governmental (such as education institutions, media, associations, organizations), 5) to improve structures of democratic institutions, and 6) to develop social dialogue among private, public and civil society organizations. See: The European Union, "Central Asia Indicative Programme (2007 - 2010)", Regulation (EC) No. 1905/2006, pp. $21-23$. http://ec.europa.eu/external_relations/ceeca/c asia/nip_07_10_en.pdf.

${ }^{18}$ The European Union, "European Community Regional Strategy Paper for Assistance to Central Asia for the Period 2007 - 2013", $\mathrm{http} / / /$ ec.europa.eu/external_relations/ceeca/c_asia/07_13_en.pdf. 
To achieve these aims, the Union plans to provide assistance to these areas:

1) In the context of the regional cooperation: INOGATE, TRACECA, the EU - Black Sea - Central Asia energy corridor, environment, border management, organized crimes, and fighting against terrorism.

2) In the context of the eradication of poverty and improvement of living standards: social development, the development of urban areas, and agricultural sectors, and other national sectors.

3) In the context of the good governance and economic reforms: political reforms, strengthening states institutions, supporting civil societies, democratization and trade.

\section{Obstacles and Suggestions}

The transformation of the Central Asian states to more democratic and liberal ones in the short- and medium terms is not an easy task for the Union.

The main handicap is the authoritarian mentality of the regional regimes. In the meantime, the regional leaders have provided some privileges to their clans in order to preserve their regimes. ${ }^{19}$ As a result, bad governance, corruption, radical movements and illegal migration have become ordinary issues due to the weak administrative institutions and existence of the privileged clans in these countries. For that reason, the leaders and the privileged clans have viewed any democratic, economic and political reforms as a threat to their political and economic positions; therefore, they have made serious attempts to stop or slow down the reforms. In the end,

\footnotetext{
${ }^{19}$ For Kazakhstan case, see: Bhauna Dave, "The EU and Kazakhstan: Balancing Economic Cooperation and Aiding Democratic Reforms in the Central Asian Region", CEPS Policy Brief, Centre for European Policy Studies, No 127, May 2007. For further information about the developments in the region, see also: Eugheniy Zhoutis, "Democratization and Human Rights in Central Asia: Problems, Development Prospects and the Role of the International Community", CEPS Policy Brief, Centre for European Policy Studies, No 134, July 2007.
} 
the regional regimes do not support any EU project that demands the promotion of civil society organizations and more political participation. They began to pursue more suppressive policies in order to protect their regimes, especially after the colorful revolutions. In this context, they openly violated the human rights, such as freedom of expression and freedom of press. ${ }^{20}$

Secondly, the European Union has only provided know - how assistance to the regional countries up to the present, but it is not enough to bring its strategies to the life effectively. For that reason, the Union has to have close relations with local firms, non governmental organizations and governmental institutions in order to realize effective implementation of the projects. It also has to monitor the projects closely and it has to provide financial assistance to the projects that focus on more specific issues. These projects should also take special conditions of the region into account. Lastly, it has to provide direct support to the local civil society organizations. ${ }^{21}$

Thirdly, the European Union has to open its representatives in all Central Asian countries. The Union has only one representative in Almaty today. Nevertheless, its representatives can play a very constructive role in getting direct and reliable knowledge about the regional affairs, providing facilities to the European researchers and investors, monitoring the regional projects closely, and preparing TACIS strategy papers in a true and reliable way.

Fourthly, unlike other regional and external powers the EU has not been motivated by a logic of great power struggle in the region, which is called the "New Great Game". This is an advantage for the EU to cooperate with other regional powers such as Russia and China in order to implement the regional projects collectively, such as TRACECA, INOGATE. 22 From this point of view, the European Union should continue to follow its existing attitude, and to support the projects that provide regional development and improve the living

${ }^{20}$ International Crisis Group, "Uzbekistan: Europe's Sanctions Matter", Policy Brief, Asia Brief, No 54, 6 November 2006.

${ }^{21}$ International Crisis Group, Central Asia: What Role, pp. 12, 23.

${ }^{22}$ Neil J. Melvin, "The European Union's Strategic Role in Central Asia", CEPS Policy Brief, Centre for European Policy Studies, No 129, March 2007. 
conditions in the region. Meanwhile, it should also continue its aim of contributing to the transformation of the region within the framework of prevailing contemporary values rather than acting as a strategic competitor.

Fifthly, in contrast to the US approach which encourages colorful revolutions for a rapid transformation in the region, the EU should push for a democratic evolution in a lengthy of time. Today, the Central Asian states do not have effective democracies but it is also clear that the colorful revolutions are not influential instruments to make their democracies more effective. Therefore, the European Union has to make serious attempts, such as implementing Erasmus programs, in order to create next generations who are familiar with the European values in the long-term period. For that reason, the European Union has to encourage the regional young people to be educated at the European Universities in order to embrace the contemporary values, such as human rights, as their own properties. In the meantime, the European universities and/or research centers can inform them about the European values while being in cooperation with the local education institutions and research centers.

\section{Conclusion}

Since 1991, the Central Asian states have spent their energies to develop relations with the Western world in order to find immediate solutions to their domestic economic, social and administrative difficulties and to weaken Russia's dominant position in the region. In this context, the regional countries have cooperated with the United States, NATO, the European Union and other Western institutions in the fields of energy, trade, economy and security.

As mentioned above, NATO, OSCE, and the European Council have established close relations without any delay. The United States preferred to follow the "Russia First" policy at the beginning, in which it focused on the Russia's nuclear capability and its economic and political reforms. Since then, the US administration changed its Caspian Sea strategy and attempted to dominate the energy resources of the region. In the meantime, a strategic competition took place in 
the Caspian Sea basin whose actors were Russia, China, Iran, Turkey and the United States.

On the other hand, the European Union did not follow such a competitive policy which aimed at becoming a party in the New Great Game. It preferred to find concrete solutions to the needs of the regional countries by adopting technical assistance programs. However, the Union has changed its Central Asia policy in a radical way parallel to the US's Broader Middle East Initiative after the September 11 attacks. It has placed democracy, respect for human rights, good governance, eradication of poverty and other contemporary values at the center of its policy. Yet, there are serious handicaps that will prevent the Union from realizing its new strategy.

Consequently, the European Union has made serious contributions to the reforms of the state institutions of the regional states and their economic systems since their independence. Although the European Union has aimed at changing mentalities of the regional countries in conformity with the democratic values and free market economies within very short time, the Union cannot seriously encourage the regional countries to make significant political reforms due to the fact that the regional leaders will concern such attempts as a threat to their existing regimes/powers. However, the Union should create new generations who have embraced democratic values through educational exchange programmes. 